\title{
ROTTINEFSCH-MALEISCHE WOORDENLIJST.
}

De hierachter volgende Rottineesch-Maleische Woordenlijst, samengesteld door den onderwijzer Tello, hoe onvolledig ook, getuigt van ijver en goeden wil. Men ziet er uit, welke hulp men van inlanders verwachten mag. Had ile samensteller de voorlichting van eenen Europeaan gehad, die eenigszins op de hoogte was van taalstudie, dan zou hij, ik twijfel er niet aan, in staat geweest zijn bij de meeste woorden voorbeelden van hun gebruik in korte volzinnen te geven. Er zou in de schrijfwijze ook meer consequentie en grooter nauwkeurigheid geheerscht hebben en de alpbabetische volgorde zou strenger volgehouden zijn. Daar eene betere rangschikking mij onmogelijk bleek zonder eene geheele, tijdroovende omwerking, wordt het handschrift hier overgedrukt, zooals het uit de pen van den samensteller gekomen is, behalve dat de oe overal vervangen is door $u$.

H. KERN. 